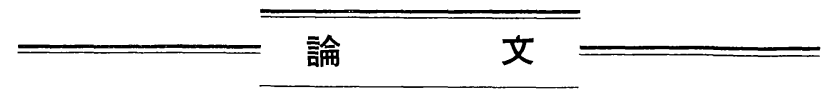

農業気象 (J.Agr. Met.) 33 (4): 175-181, 1978

\title{
The Variation of Heating Load Coefficient for a Greenhouse and Overall Heat-Transfer Coefficient through Plastic Film
}

\author{
Ikuo HORIGUCHI \\ $\left(\begin{array}{c}\text { Department of Agricultural Engineering } \\ \text { Hokkaido University, Sapporo, Japan }\end{array}\right)$
}

\begin{abstract}
The heating load coefficients were measured using a practical plastic greenhouse in 1974 and 1975. In the first year a fuel capacity of $89,000 \mathrm{kcal} / \mathrm{hr}$ for heating was used. A large variation of measured values appeared. However, the heating load coefficient can be expressed statistically by equation (3). In the next year a capacity of $26,400 \mathrm{kcal} / \mathrm{hr}$ was used to accurately determine the heating load coefficient. It was of insufficient capacity so that the inside temperature dropped slightly below the design temperature. The results were that the variation of each measured point increased over that of the test in the first year.

For investigating the variation of the heating load coefficient, model tests were performed using polyvinyl chloride (p.v.c.) film. In the model tests only the overall heat-transfer coefficient, which greatly affected the heating load coefficient, was able to be investigated. A large variation in the values of the overall heat-transfer coefficient from the model tests was shown when they were plotted against wind velocity. However, when the overall heat-transfer coefficient was plotted against the ratio of the convective heat-transfer to the radiative heat-transfer, a regular curve was able to express with sufficient accuracy the overall heat-transfer coefficient. Moreover, in tests using the various materials the same results were obtained. According to them, a large overall heat-transfer coefficient appeared when the radiative heat-transfer was large in comparison to the convective heat-transfer. On the contrary, the overall heat-transfer coefficient was nearly constant, if the convective heattransfer was large.
\end{abstract}

\section{Introduction}

Recently, plastic greenhouses equipped with heating systems have come into wide use. For determining the capacity of heaters the so-called heating load coefficient is of considerable importance. Many investigators have studied this subject and the determination of its standard values for designing the heating system was tried by the Society of Agricultural Meteorology of Japan (SAMJ 1977). However, a wide variation in the values of heating load coefficient has been reported (Nakagawa et al. 1974, Sheldrake et al. 1962,
Takakura et al. 1971, Vogel et al. 1961, Whittle et al. 1960, Yamamoto 1970). This variation may be related to the use of different heating systems, the method of measurement, experimental error, non-constancy of heating load coefficient and possibly other factors.

This paper discusses the variation of the heating load coefficient and the overall heat-transfer coefficient through plastic film. First we measured the heating load coefficient for a practical plastic greenhouse and second the variation of overall heat-transfer coefficient by using a model.

Presented at the Annual Meeting, 12 June 1977.

Received 7 November 1977. 


\section{Measurement of heating load coefficient} for a practical plastic greenhouse

To calculate the greenhouse heating load the following equation has been used

$$
H=U \cdot A \cdot\left(t_{\mathrm{i}}-t_{\mathrm{o}}\right),
$$

where $H$ is the heat consumption, $A$ the wall and roof surface area, $U$ the heating load coefficient, $t_{\mathrm{i}}$ inside air temperature and $t_{\mathrm{o}}$ outside air temperature.

When $U$ is known, it is relatively easy to calculate the total heat loss. Therefore, it is important to accurately determine the heating load coefficient $U$. Generally, $U$ is given by an equation

$$
U=a+b V
$$

where $a$ and $b$ are empirical constants and $V$ is wind velocity. The author tried to determine the constants $a$ and $b$ by using a practical plastic greenhouse.

\section{(a) Methods and materials}

The measurements were performed for 20-30 nights in May 1974 and April and May 1975. A description of the plastic greenhouse is given in Fig. 1.

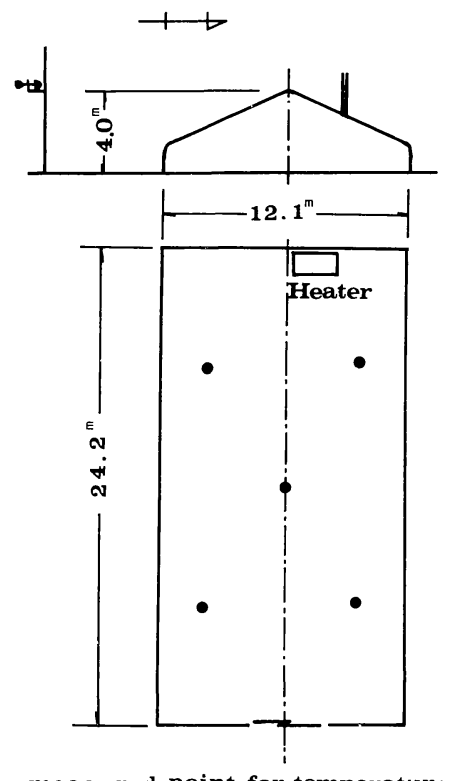

- measured point for temperature

Fig. 1. A description of the plastic greenhouse for measuring the heating load coefficient.

(plastic cover, polyvinyl chloride film of $0.1 \mathrm{~mm}$, surface area of wall and roof $455.6 \mathrm{~m}^{2}$, area of floor $292.8 \mathrm{~m}^{2}$, capacity of heater $87,000 \mathrm{kcal} / \mathrm{hr}$ (1974), 26,400 $\mathrm{kcal} / \mathrm{hr}(1975))$
The heating installations were of an air heating type, which were controlled by an on-off thermostat. A different fuel capacity was used each of the two years. In 1974 the capacity was 89,000 $\mathrm{kcal} / \mathrm{hr}$ and in 1975 it was $26,400 \mathrm{kcal} / \mathrm{hr}$.

Temperature, inside and outside, was measured with a recording electrical resistance thermometer. In addition five and ten thermocouples respectively in 1974 and in 1975 were used to measure the difference between inside and outside temperatures. The data of temperature were integrated for one hour and the hourly mean temperature was then calculated from the integrated data. The difference between inside and outside temperatures and the data from the resistance thermometer and five or ten thermocouples were averaged and used for calculating the heating load coefficient.

Total heat supplied to the plastic greenhouse was calculated from the fuel consumption by the heater minus the heat loss through the ventpipe. Wind velocity was measured at a height of 4 meters above ground.

(b) Results and discussion

A summary of the work done in 1974 is shown in Fig. 2.

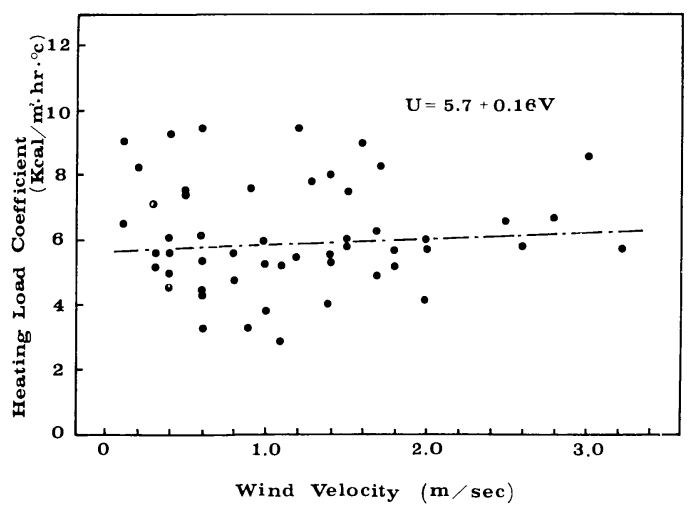

Fig. 2. Relationship between heating load coefficient and wind velocity using a fuel capacity of $89,000 \mathrm{kcal} / \mathrm{hr}$.

$U$ is expressed by the following equation which is derived statistically

$$
U=5.7+0.16 \mathrm{~V} .
$$

Each measured point, however, varied over a wide range, about 3.0 to $10.0 \mathrm{kcal} / \mathrm{m}^{2} \cdot \mathrm{hr} \cdot{ }^{\circ} \mathrm{C}$. It is problematical whether the variation is caused by experimental error or it actually takes place under certain conditions. If it is only the experimental 
error, more reliable measurements of $U$ must be made. It appears that the calculation of the total heat supplied is a possible source of error. For example, if the controller operates on-off 3 or 4 times per hour under a certain meteoric condition, there is much difference in the heat supplied between the case of 3 times per hour and the case of 4 times per hour in spite of the stationary meteoric condition. Moreover, it was difficult to calculate the residual heat in the heater when it was off.

For a more exact determination of the heating load coefficient the plastic greenhouse was heated continuously with the small heater which operated nearly continuously during the experiment. The heater did not have enough capacity so the inside temperature dropped slightly below the design temperature. But, it allowed $U$ to be accurately determined as compared with the previous experiment. The results are shown in Fig. 3.

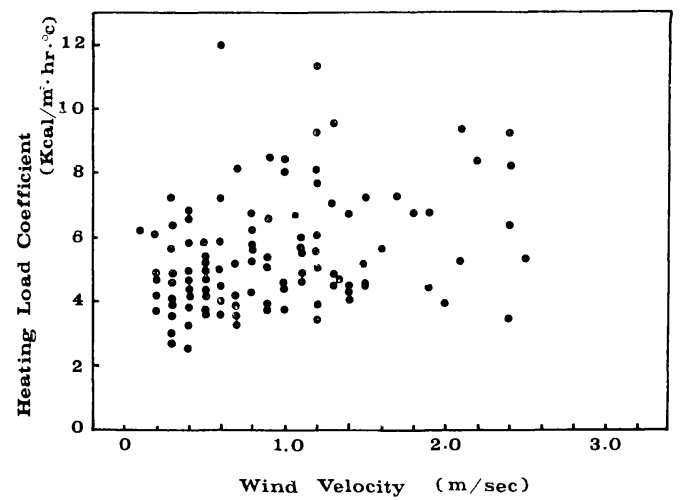

Fig. 3. Relationship between heating load coefficient and wind velocity using a fuel capacity of $26,400 \mathrm{kcal} / \mathrm{hr}$.

According to Fig. 3, the variation of each measured point increased over that in the previous measurement so that the error in the calculations of the total heat supplied and the residual heat in the heater do not appear to have caused the wide variation illustrated in Fig. 2.

For investigating the cause of the variation of $U$ the model tests were performed.

\section{Measurement of the overall heat-transfer coefficient using model}

The heat consumption of a greenhouse $H$ can also be shown by the following equation

$$
H=H_{\mathrm{s}}+H_{\mathrm{v}}+H_{\mathrm{o}}
$$

where $H_{\mathrm{s}}$ is the heat loss into the soil, $H_{\mathrm{v}}$ is the heat loss due to ventilation and $H_{\mathrm{o}}$ is the overall heat-transfer through the plastic film. These terms can be expressed as functions of temperature difference. They can then be rewritten into following forms

$$
\begin{aligned}
& H_{\mathrm{s}}=h_{\mathrm{s}} \cdot A_{g} \cdot\left(t_{\mathrm{i}}-t_{\mathrm{s}}\right) \\
& H_{\mathrm{v}}=h_{\mathrm{v}} \cdot A \cdot\left(t_{\mathrm{i}}-t_{\mathrm{o}}\right) \\
& H_{\mathrm{o}}=h_{\mathrm{o}} \cdot A \cdot\left(t_{\mathrm{i}}-t_{\mathrm{o}}\right)
\end{aligned}
$$

where $h_{\mathrm{s}}$ is the heat-transfer coefficient into soil, $h_{\mathrm{v}}$ is the heat-transfer coefficient due to ventilation, $h_{\mathrm{o}}$ is the overall heat-transfer coefficient, $t_{\mathrm{s}}$ is the soil surface temperature and $A_{g}$ is the area of the floor.

The value of $H_{\mathrm{s}}$ is small compared with the others, being about $5-10 \%$ of total heat loss (Businger 1966, Takakura et al. 1971, Yamamoto 1973). Therefore, $H_{\mathrm{s}}$ can be replaced by the following approximate equation

$$
H_{\mathrm{s}}=a^{\prime \prime} \cdot A \cdot\left(t_{\mathrm{i}}-t_{\mathrm{o}}\right),
$$

where $a^{\prime \prime}$ is an empirical constant.

The ventilation rate is a function of wind velocity, temperature difference and the size and number of air leaks in the wall. Both the wind velocity $V$ and the temperature difference $t_{\mathrm{i}}-t_{\mathrm{o}}$ will cause a pressure difference over the greenhouse wall, which is actually the cause of the ventilation. Therefore, the following equation may be substituted for the heat-transfer coefficient due to ventilation (Okada et al. 1973).

$$
h_{\mathrm{v}}=a^{\prime}+b^{\prime} V,
$$

where $a^{\prime}$ and $b^{\prime}$ are empirical constants. About $20-30 \%$ of the total heat loss from a greenhouse is due to ventilation (Takakura et al. 1971).

About $60-80 \%$ of the total heat loss is due to the overall heat-transfer through plastic film, so a great part of $U$ is occupied by the overall heattransfer coefficient (Takakura et al. 1971). Thus, it is important to correctly calculate it. If $h_{\mathrm{o}}$ is constant or is a function of wind velocity, then by combining equations (6), (7), (8) and (9), $U$ can be expressed as equation (2).

In the following experiments the overall heattransfer coefficient which greatly affects the heating load coefficient was investigated. 


\section{(a) Methods and materials}

The three boxes shown in Fig. 4 were designed for the experiments. To simplify experimentation only the upper face was covered with plastic film. The side and bottom walls were made of three layers of insulating materials with the inside and outside surfaces of the walls covered with silver p.v.c. film to prevent leakage of air.

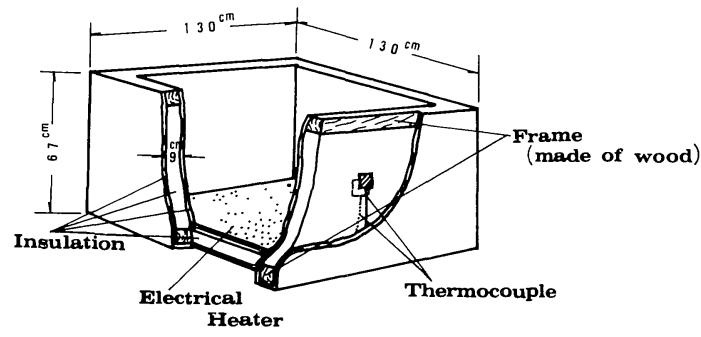

Fig. 4. A description of model box for measuring the overall heat-transfer coefficient.

Thermocouples were set in the insulation layers for calculating heat loss through the walls. Heat was supplied using a sheet of carbonic heating film placed in the bottom of each box. Each sheet was connected to an on-off controller.

The difference between inside and outside temperatures was measured by the thermocouples. The electric current supplied to the boxes for heating and all temperature readings were integrated for thirty minutes and then used to calculate the overall heat-transfer coefficient. The anemometer was set at the same level as the upper film surface of the boxes and the radiometers (Funk type) were located at $10 \mathrm{~cm}$ above the plastic film of each box.

If the amount of heat loss due to ventilation is disregarded, the heat budget of the experimental box can be expressed by the following equation

$$
Q=H_{\mathrm{b}}+H_{\mathrm{w}}+H_{m},
$$

where $Q$ is the heat supplied by the electrical heater, $H_{\mathrm{b}}$ and $H_{\mathrm{w}}$ are the heat losses through the bottom and side walls respectively, and $H_{m}$ is the overall heat-transfer. It is also expressed as the function of the difference in temperatures between inside and outside $t_{\mathrm{i}}-t_{\mathrm{o}}$. So, the overall heattransfer coefficient $h_{m}$ is given by the following equation

$$
h_{m}=\frac{Q-H_{\mathrm{b}}-H_{\mathrm{w}}}{A_{\mathrm{o}}\left(t_{\mathrm{i}}-t_{\mathrm{o}}\right)},
$$

where $A_{\mathrm{o}}$ is the area of plastic film. In this experiment $h_{m}$ was calculated by equation (11).

(b) Results and discussion

The results of a model test using clear p.v.c. film of $0.1 \mathrm{~mm}$ are shown in Fig. 5 .

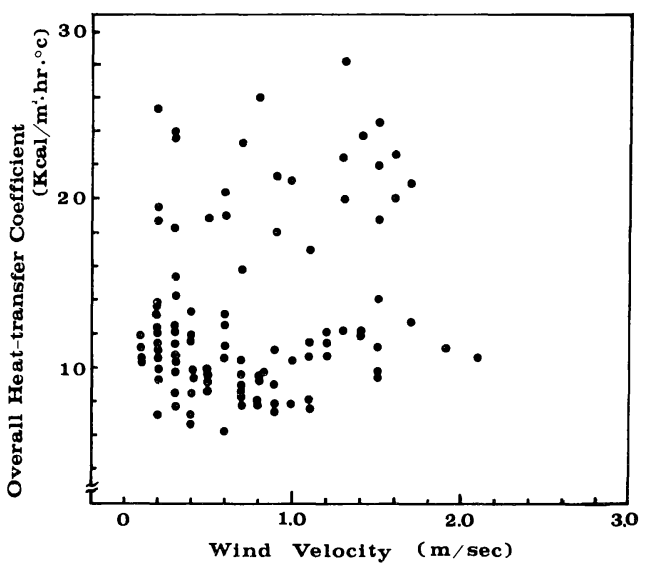

Fig. 5. Relationship between the overall heattransfer coefficient and wind velocity in model tests.

There was a large variation of $h_{m}$ and $h_{m}$ could not be expressed as a function of wind velocity. This fact suggests that the overall heat-transfer for the plastic film may not be expressed as equation (7).

The overall heat-transfer is composed of two parts of heat-transfer, that is, the convective heattransfer and the radiative heat-transfer. The convective part including the conductive transfer in the film can be expressed as a function of temperature difference $t_{\mathrm{i}}-t_{\mathrm{o}}$ as in equation (7), but the radiative heat-transfer is a function of surface temperature and radiation from the atmosphere. Consequently, if the value of the convective heat-transfer is very large in comparison with the value of the radiative heat-transfer, the overall heat-transfer can then be accurately calculated by equation (7). If the value of the radiative heat-transfer is larger than the value of the convective heat-transfer, the result calculated using equation (7) will be inadequate. So, the author investigated the relationship between $h_{m}$ and the ratio of the convective part to the radiative part.

The value of the convective part was calculated by the following equation 


$$
H_{\mathrm{c}}=\frac{A_{0}}{\frac{1}{\alpha_{\mathrm{i}}}+\frac{l}{\lambda}+\frac{1}{\alpha_{\mathrm{o}}}}\left(t_{\mathrm{i}}-t_{0}\right),
$$

where $H_{\mathrm{c}}=$ the convective heat-transfer,

$\alpha_{\mathrm{i}}=$ the heat-transfer coefficient of the inside air calculated by $\alpha_{\mathrm{i}}=2.8 \sqrt[4]{\Delta t}$, $\Delta t$ being difference between film and inside air temperature, which is assumed that $\Delta t=t_{\mathrm{i}}-t_{\mathrm{o}} \quad$ (Watanabe 1965),

$\alpha_{0}=$ the heat-transfer coefficient of the outside air calculated by $\alpha_{0}=2.8 \sqrt[4]{\Delta t}$ $+3.3 V^{0.8}$ by use of $\Delta t=t_{\mathrm{i}}-t_{\mathrm{o}}$ (Mikheyev 1966, Watanabe 1965),

$l=$ thickness of materials $(0.1 \mathrm{~mm}$ for plastic film and $3.0 \mathrm{~mm}$ for glass),

$\lambda=$ the heat conductivity of materials $\left(0.12 \mathrm{kcal} / \mathrm{m} \cdot \mathrm{hr} \cdot{ }^{\circ} \mathrm{C}\right.$ for p.v.c. film, $0.14 \mathrm{kcal} / \mathrm{m} \cdot \mathrm{hr} \cdot{ }^{\circ} \mathrm{C}$ for polyethylene film and $0.64 \mathrm{kcal} / \mathrm{m} \cdot \mathrm{hr} \cdot{ }^{\circ} \mathrm{C}$ for glass)

The radiative heat-transfer was calculated from the data of the radiometer and equation (13) of the heat budget under the assumption that there was no heat-transfer due to ventilation.

$$
H_{\mathrm{r}}=Q-H_{\mathrm{w}}-H_{\mathrm{b}}-H_{\mathrm{c}},
$$

where $H_{\mathrm{r}}$ is the radiative heat-transfer.

The results are shown in Fig. 6, in which the abscissa is the ratio of the convective to the radiative heat-transfer.

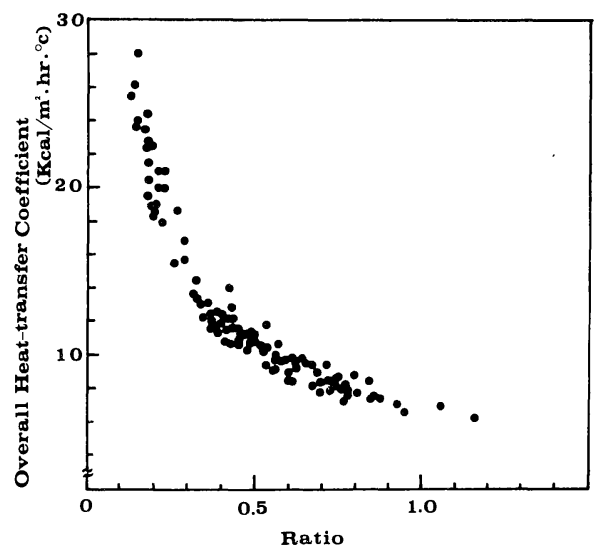

Fig. 6. Relationship between the overall heattransfer coefficient and the ratio of convective heat-transfer and radiative heat-transfer.

The measured points conform closely to a regular curve. The overall heat-transfer coefficient $h_{m}$ increases as the proportion of radiative heattransfer increases in the overall heat-transfer, that is, decrease in the ratio $H_{\mathrm{c}} / H_{\mathrm{r}}$. On the contrary, when the convective heat-transfer has the larger value in the overall heat-transfer, $h_{m}$ approaches a constant value. It is considered that the variations in Fig. 5 are caused by the large values of the radiative heat-transfer compared with those of the convective heat-transfer.

Then, experiments were performed using two boxes. One was maintained at a constant inside temperature. The other one was operated with a constant electric current in the heater by means of a controller. In the latter box, the inside temperature changed with the outside temperature. With the constant current the values of $h_{m}$ varied to a much greater degree than those in the box at a constant temperature. This was because the inside temperature in the latter decreased with the falling outside temperature and the difference between the inside and outside temperatures became small. Then, there was a relative increase in the radiative heat-transfer in comparison with the convective heat-transfer and the large values of $h_{m}$ appeared. This is a likely reason that the variations in experiments in 1975 were larger than those in 1974.

Furthermore, experiments with the boxes covered with polyethylene (p.e.) film with $71 \%$ transmittance of long-wave radiation, silver p.v.c. film with $0 \%$ transmittance (Hagiwara and Horiguchi 1972) and glass with about $7 \%$ transmittance (Hanson 1963) were performed in April, May and June of 1976 and 1977. According to the results (see Fig. 7) each measured point fell on a curve in spite of the different properties of materials.

The ratio $H_{\mathrm{c}} / H_{\mathrm{r}}$ varied from 0.1 to 1.0 and many measured points concentrated in the range of 0.4 to 0.7 . This illustrates the fact that the relation between $h_{m}$ and the ratio is not affected by the conductivity and the transmittance of long-wave radiation of a thin material used. And, there are many cases when $h_{m}$ is not constant.

Computations of $h_{m}$ using simulated values of wind velocity $1.0 \mathrm{~m} / \mathrm{s}$, radiative heat-transfer $0.01-$ $0.20 \mathrm{cal} / \mathrm{cm}^{2} \cdot \mathrm{min}$ and temperature difference $0.1-15.0^{\circ} \mathrm{C}$, were made using equation (12) for the convective heat-transfer. The results are shown in Fig. 8. 


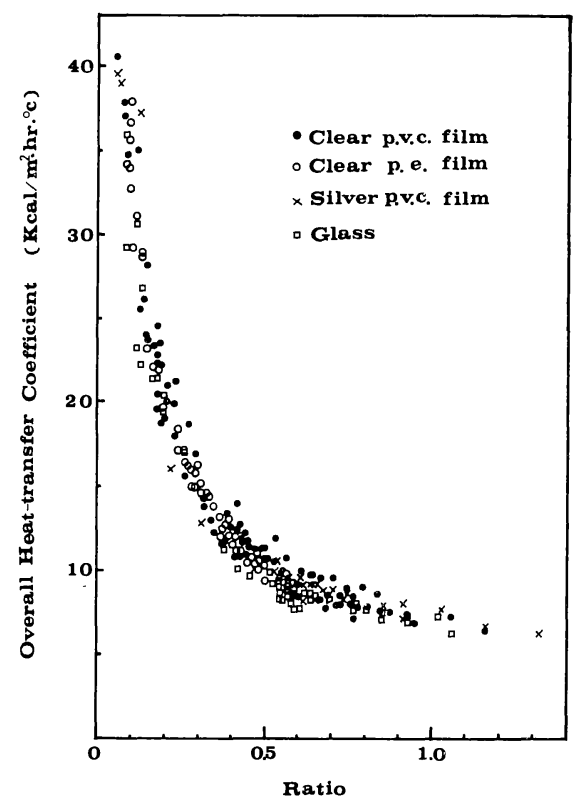

Fig. 7. The overall heat-transfer coefficient and ratio $\left(H_{\mathrm{c}} / H_{\mathrm{r}}\right)$ obtained by various materials.

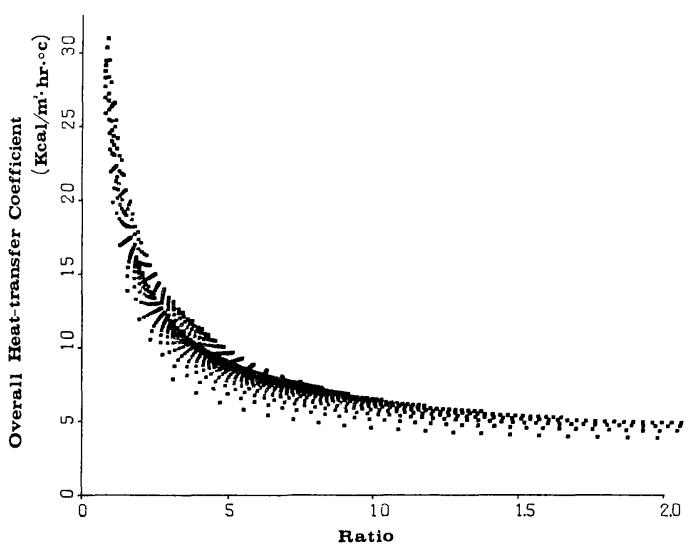

Fig. 8. The computation of overall heat-transfer coefficient and ratio $\left(H_{\mathrm{c}} / H_{\mathrm{r}}\right)$ using the simulated values; clear p.v.c. film of $0.1 \mathrm{~mm}$, wind velocity of $1.0 \mathrm{~m} / \mathrm{s}$, radiative heattransfer of $0.01-0.20 \mathrm{cal} / \mathrm{cm}^{2} \cdot \mathrm{min}$ and temperature difference of $0.1-15.0^{\circ} \mathrm{C}$.

Nearly the same curve resulted as the one from the data obtained using the model boxes and $h_{m}$ became nearly constant when the ratio was greater than 1.0.

When calculating the overall heat-transfer, we can use a constant transfer coefficient if the difference between the inside and outside temperature is large. On the other hand, if the temperature difference is small, the radiative part of the total heat-transfer becomes relatively large and the overall heat-transfer coefficient takes various values. Also, in the case of heating load coefficient consisting mainly of the overall heattransfer coefficient, the same must be the case. The surface temperature of a roof and wall made with thin materials, e.g., plastic film and glass, is greatly affected by inside temperature. When the inside temperature becomes high, the radiative component of heat-transfer is large and the heating load coefficient is likely to increase to a considerable degree. We must remember that equations (1) and (7) can be adequate only in the case of a large value of the convective heat-transfer in comparison with the radiative heat-transfer.

\section{Acknowledgement}

The author is deeply indebted to Professor D. W. Bates of University of Minnesota and to Mrs. Bates for their carefully correcting of the manuscript. The author also would like to thank Mr. Y. Higuchi and Mr. S. Hayashi of the Agricultural Center in Sapporo who allowed him to use a greenhouse in the experiments.

This work was supported in part by a research grant given by the Ministry of Education to the group represented by Dr. Mihara.

\section{References}

1) Businger, J. A., 1966: The glasshouse climate. In physics of plant environment (ed. by W. R. Van Wijk) North-Holland Publishing Company.

2) Hagiwara, M., and I. Horiguchi, 1972: The measurements of transmission of long-wave radiation through materials used for crop protection in agriculture. J. Agr. Meteor. 28, 23-28.*

3) Hanson, K. J., 1963: The radiative effectiveness of plastic films for greenhouse. J. Appl. Meteor. 2, 793-797.

4) Mikheyev, M., 1966: Fundamentals of heat transfer. Peace Publishers.

5) Okada, M., and T. Takakura, 1973: Guide and data for greenhouse air conditioning. J. Agr. Meteor. 28, 223-230.

6) Sheldrake, R., and R.W. Langhans, 1962: Heating requirement of plastic greenhouse. Proc. Am. Soc. Hort. Sci. 80, 666-669.

7) The Society of the Agricultural Meteorology of Japan, 1977: J. Agr. Meteor. 33, special 
number.*

8) Takakura, T., and M. Okada., 1971: Experimental determination of greenhouse heating load coefficient. J. Agr. Meteor. 27, 93-97.*

9) Vogel, G., and A. Heissner, 1961: Comparative investigations on glass- and plastic-covered greenhouse. Ach. Gar. 9, 3-25.

10) Watanabe, K., (ed.), 1965: Kenchiku-KeikakuGenron III. Maruzen Co., Tokyo.*
11) Whittle, R. M., and W. J. C. Lawrence, 1960: The climetology of greenhouse V, J.Agr. Eng. Res. 5, 399-405.

12) Yamamoto, Y., 1970: On the heat loss coefficient of plastic greenhouse. J. Agr. Meteor. 26, 117-122.*

* written in Japanese

\section{ハウスの暖房負荷係数の変動と プラスチックフィルムの熱貫流率について}

堀口郁夫

(北海道大学農学部)

要

実際に使用しているビニルハウスを使用して，暖房負 荷係数の測定を行った。1974年は,89,000 kcal /hrの温風 暖房器を使用して測定を行い，式(3)のような值が得られ たが，各測点はかなりのバラツキがみられた。これは on-off 調節により供給熱量が正確に测定出来ないこと が原因上考え，1975 年には正確な測定を行うため, onoff 作動が少ない $26,400 \mathrm{kcal} / \mathrm{hr}$ の暖房器を使用して 測定を行った。しかし図 3 のように各測定のバラツキは さらに大きくなった。このバラッキの原因を調べるため， モデル箱を使用して，暖房負荷係数に大きな比率をしめ
約

る熱貫流率を調べた。その結果, 熱貫流率を風速の関数 として表わした場合，各測点はバラッキのため一定の関 係式は得られなかったが，熱貫流量にしめる顕熱損失之 放射熱損失の比の関数として表わした場合，一定の曲線 上に熱貫流率はならんだ。さらにての曲線はプラスチッ クフィルムの種類やガラスによる相違は小さく，ビニル， ポリエチレン, シルバービニル, ガラスともほぼ同じ曲 線になった。この曲線から熱貫流量にしめる顕熱損失が 多いと一定の熱貫流率になるが，放射熱損失が多いと， 熱貫流率が大きく変動することが判明した。 